BÓNA Péter - HORVÁTH Csaba

\title{
FELDOLGOZÓIPARI VÁLLALKOZÁSOK MÚKÖDÉSE A FENNTARTHATÓSÁG ÉRDEKÉBEN
}

A globalizáció hatására a vállalatok között a verseny sokkal élesebb, mint korábban Milyen eszközök segítségével tudnak a vállalatok a feldolgozóiparban sikereket elérni a 2008-ban bekövetkezett gazdasági válság után kialakult törékeny rendszerben? A tanulmány egy a teljes vállalati sikert vizsgáló kutatás fenntarthatóságra vonatkozó szegmensére összpontosít, mivel a fenntarthatóság sikerkomponens első́dlegessé vált a siker megállapításánál. Már nem elég csak a piaci szempontokra koncentrálni. Azt is figyelembe kell venni, hogy a vállalatoknak milyen a környezeti és társadalmi teljesítménye. A tanulmány célja annak feltárása, hogy a stratégiaimenedzsment-rendszer koncepciójának komponensei hogyan hatnak a kiemelkedó fenntarthatóságra. A kutatás a korábbi sikerkutatásokat alapul véve meghatározza a befolyásoló sikertényezőket és azok csoportjait faktorelemzéssel, továbbá lineáris regressziós modelleket felhasználva magyarázza a sikert, összpontosítva a fenntarthatóságra. A sikert leíró sikerkritériumok eszköze egy olyan balanced scorecard, amely - a gyakorlati kutatások közül elsôként - a fenntarthatósággal kiegészítve, öt nézőpont szerint vizsgál. A kapott eredmények azt mutatják, hogy a szervezetek elsősorban a stratégiai és strukturális eszközök használatával érnek el fenntarthatósági szempontból kiemelkedó eredményeket, és kevésbé származik előnyük a kulturális és vezetési tényezőkből. Továbbá az tapasztalható, hogy ma Magyarországon a feldolgozóiparban a fenntarthatóság elsősorban a vevók irányában kínál közvetlen módon értéket, ami indirekt módon segíti elő a pénzügyi sikerességet.

\section{Kulcsszavak: balanced scorecard, fenntarthatóság, siker, sikertényezők}

A siker, egy a múltban meghatározott jövőbeni állapot elérése, amire mindenki vágyik, legyen az személy, vagy gazdasági szervezet. A különböző korokban más volt a siker kulcsa. A gazdasági világ folyamatos gyorsulása, a távolságok jelentéktelenné válása miatt ez a kulcs egyre összetettebb, bonyolultabb lett. Jelenleg a globalizáció szinte megállíthatatlan (Brebán, 2009). Nincsenek távolsági korlátok, a gyors reagálás az egyik legfontosabb elvárás a piaci versenyben maradni szándékozó vállalatokkal szemben (Csath, 2008). A siker ezért szoros kapcsolatban van a versenyképességgel, mert egy szervezet sikere a versenyben való hosszú távú helytállást, a szervezet versenyképességének hosszú távú biztosítását jelenti (Dinya, 2008).

Egy vállalat sikere több érintett irányába kifejtett teljesítményekből tevődik össze. Jelen tanulmány a társadalmi, környezeti hatásokra összpontosít, a fenntarthatósági sikerrel foglalkozik. Annak feltárásával, hogyan lehet egy vállalat fenntarthatósági nézőpont- ból sikeres, ilyen irányú teljesítménye még jobb. Jelenleg kiemelt szerepet kap a fenntarthatóság (Balaton et al., 2014). A globális piaci körülmények között a vállalatoknak már nemcsak egy célt, a tulajdonos érdekeit kell szem elôtt tartaniuk, hanem az összes érintett számára értéket kell biztosítaniuk (Porter - Kramer, 2007). Egy vállalat fenntarthatósági sikere azt jelenti, hogy kiemelkedő a környezeti, egészségügyi, biztonsági, foglalkoztatási és közösségi teljesítménye. Nemcsak magát, hanem környezetét is folyamatosan fejleszti, jobbá teszi.

Jelen tanulmány egy a teljes vállalati sikerre vonatkozó kutatás fenntarthatóságra vonatkozó részét helyezi előtérbe. Azonosítja és rendszerezi a múltban sikertényezóként aposztrofált stratégiaimenedzsment-eszközöket. Minden érintett bevonásával meghatározza a sikert leíró kritériumokat, és statisztikai elemzésekkel feltárja, a vállalatok fenntarthatósági sikerével kapcsolatos hatásokat. Vizsgálatunk célja megmutatni, mely sikertényezők milyen módon hatnak a 
fenntarthatósági teljesítményre, illetve annak feltárása, hogy ez az eredmény miként generál kiemelkedő teljesítményt a további érintettek számára.

\section{A fenntarthatóság elótérbe kerülése}

A fenntarthatóság a jelenlegi szükségletek kielégítése a környezeti és társadalmi érdekek figyelembevételével. A XXI. század egyik legjelentősebb kihívása, amelyre az Európai Bizottság 2010-ben elindított Európa 2020 Stratégiája a gazdasági krízisből való kilábalás egyik meghatározó hajtóerejeként tekint (Fülöp, 2013). Egyre nagyobb körben válik elfogadottá, hogy a környezeti és társadalmi szempontok figyelembevétele kikerülhetetlen a szervezetek hosszú távú fennmaradásához, sikeréhez (Balaton et al., 2014). A fenntarthatóság vállalati szinten jelenleg azt jelenti, hogy a korábbi, csak gazdasági szemléletmódot fel kell váltania a gazdasági, környezeti és társadalmi optimalizálás hármas szempontrendszerének (Bárth-Fehér, 2012). A szervezetek arra törekednek, hogy gazdaságilag életképesek legyenek, a környezetet ne terheljék és a társadalom számára is felelős, támogató szerepet töltsenek be (Angyal, 2005). Az új szempontokkal a stratégiai gondolkodás időtávja rendkívül megnövekedett, mert a környezeti és társadalmi hatások esetén muszáj hosszú távon gondolkodni, mivel a jelen cselekményeinek hatása, az addigi szempontokkal ellentétben sokkal később jelentkezik. Megjelent a fenntarthatósági stratégiai menedzsment, ami lehetóvé teszi a szervezetek számára olyan stratégiai eszközök és módszerek fejlesztését, amelyekkel megóvható a környezet, és a társadalmi jólét is biztosítható. (Fülöp - Hódi Hernádi, 2014) Alapvető elvárássá vált a fenntartható múködés, ami egyben alapfeltétele is a sikeres vállalati múködésnek.

\section{A sikerkutatások eredményei napjainkig}

Számos munka született arról, hogy a stratégiai menedzsment mely tényezői segítik elő egy vállalat sikerességét. Sok sikertényezőt azonosítottak, de alapvetôen mindegyik a stratégiaimenedzsment-rendszer koncepciójának meghatározó összetevőire, a stratégia, struktúra, kultúra, illetve a vezetés területére vonatkoztatható.

Az első jelentôs lépést T. J. Peters és R. H. Waterman (1982) kutatása jelentette. Minden területre fókuszáltak, amely során több sikertényezőt azonosítottak. Strukturális eszközként a vevőkkel való szoros kapcsolat kialakítását, de meghatároztak emellett kulturális és vezetési eszközöket is, mint az értékrendszer folyamatos tudatosítása, és a szúk felsô vezetés, ami gyorsabb döntéseket, rugalmasabb múködést eredményez véleményük szerint.
A további kutatások nagy része viszont a stratégiához köthető tényezőket tartja a siker meghatározó eszközének. Grove (1997), illetve Eisenhardt és Brown (1998) az idő̈itemezést, mint központi eszközt azonosították. Véleményük szerint azok a vállalatok lesznek sikeresek, amelyek nemcsak a piaci változásokra reagálnak, hanem múköódésüket egy meghatározó ritmus vezérli, ami által a versenytársak előtt járnak. Collins és Porras (2000) a hosszú távú tervek és a proaktív cselekedeteket hangsúlyozzák, de emellett a kulturális eszközök fontosságára is felhívják a figyelmet, mint az alapvetó értékeket megórző kultúra és a vezetôk kinevelése. Stratégiai sikertényezőként Foster és Kaplan (2001) a gyengén teljesító üzletek megszüntetésére, Zook és Allen (2001) pedig a kapcsolódó üzletágak felé történő terjeszkedésre összpontosít. Ezt követően vált fontos stratégiai eszközzé a felelősségvállalás. A vállalatok felfedezték, hogy megfelelő stratégiával a sikert elősegítő eszköz lehet (Porter - Kaplan, 2007). Ezt később Németh (2013) és Braun (2013) is megerósíti. A strukturális megoldások jelentőségét Joyce és munkatársai (2003) helyezték előtérbe. A siker kiváltójának vélték az egyszerú tagoltságot és a döntéshozatal közel helyezését a vevőhöz. Viszont hasonlóan Peters és Waterman kutatásához nemcsak egy területre fókuszáltak, így sikertényezőként határozták meg a stratégia folyamatos finomhangolását, illetve kommunikálását az érintettek irányában. Továbbá meghatározó szerepet tulajdonítottak az elismerést fontosnak tartó kultúrának, illetve már előtérbe kerültek olyan vezetési eszközök, mint a szoros emberi kapcsolatok kiépítése a vállalat munkatársai között és a vezetók részvétele a tehetséggondozásban. Spitzer (2007) is a struktúrára helyezi a hangsúlyt, és olyan szervezet kialakítását ösztönzi, amely a számszerú mérést helyezi a középpontba.

A kultúra sikeres vállalati múködésre gyakorolt hatása már a japán vállalatok térnyerésénél előtérbe került. Később Kotter és Heskett (1992) is vizsgálták, és arra jutottak, hogy befolyása meghatározó és teljesítményfokozó. A kulturális és vezetési eszközök a korábbi kutatások eredményeiben is megjelentek, de erőteljesen, a többi tényezôtól függetlenül hangsúlyosak a 2008-ban bekövetkezett gazdasági válság után lettek. Dinya (2008) a kulturális és vezetési tényezőkre is hangsúlyt helyez, amikor a több területen alkalmazható munkaerót támogató kultúrát és az intuitív, döntéseket részben delegáló vezetést sikertényezőként azonosítja. Beer (2009) a kiváló teljesítményt a kiemelkedő elkötelezettséggel társítja, és azt mondja, hogy az ezt elősegító kultúra meghatározó eleme a csapatmunka. A vezetésre vonatkozó sikertényezőknél még fontos megemlíteni Breene és Nunes (2011) kutatását. Joyce és munkatársaival egyetértve a tehetségfejlesztést, mint meghatározó eszközt hangsúlyozzák a piaci relevancia és a megkülönböztető képességek mellett. 


\section{A kutatás modellje és kontextusa}

A siker eszközeként számos tényezốt azonosítottak a múltban. Kutatásunk a stratégiai menedzsment rendszerkoncepciójából indul ki, miszerint egy szervezet múködését alapvetôen a stratégiai menedzsment három alappillére határozza meg, a stratégia, a struktúra és a kultúra. Ezt egészítettük ki továbbá a vezetéssel, mint negyedik eszközcsoporttal, mivel ez a négy tényezőcsoport kiemelt szerepet tölt be jelenleg egy vállalat sikeres múködésében (Balaton et al., 2014). A korábban azonosított sikertényezők is elsősorban erre a négy területre összpontosítanak. Jelen tanulmány azt a problémát járja körül, hogy milyen sikertényezők vannak a megállapított négy csoportban, illetve mely sikertényezők azok, amelyek jelenleg, Magyarországon a feldolgozóiparban valóban javítják a fenntarthatóság teljesítményét, elősegítik sikerességét.

A kutatás kerete a stratégiai menedzsment. A magyarázó változók a sikertényezők, magyarázott változó a siker, azon belül a fenntarthatósággal összefüggő eredmények. A sikertényező változók azonosításához az elmúlt évek sikerkutatásainak eredményei adták az alapot, sikerkritériumok esetében pedig a vállalatok egymáshoz viszonyított teljesítménye. (1.ábra)

\section{A fenntarthatósági nézőpont sikerére vonatkoztatott kutatási modell}

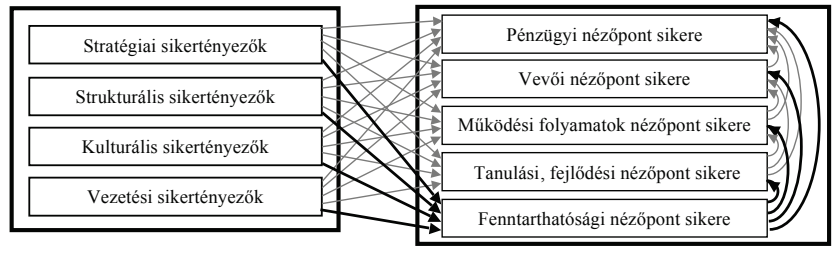

A kutatás fókuszában a Magyarországon múködő 50-nél több fót foglalkoztató, feldolgozóiparban tevékenykedő vállalatok álltak. A Magyarországon rendelkezésre álló munkaerő legnagyobb részét ezek a vállalatok alkalmazzák. Fenntarthatósági szempontból ezek a vállalatok a legaktívabbak.

A feldolgozóipar kiemelt fontosságú Magyarországon. A hazai fejlődés egyik legfontosabb motorja (Kukely, 2008). Ez nem volt mindig így. A rendszerváltást követóen mély válságba került. Rendkívül erős hatással volt rá a privatizáció (Vas et al., 2015). Viszont később több stratégiai jelentőségú befektetés valósult meg (Vápár, 2013), és a külföldi tôke erôteljes beáramlásával mára a gazdaság húzóágazata lett. A tradicionális feldolgozóipari szektorok a ruhaipar, a fa-, papír-, nyomdaés csomagolóipar, a gumi- és múanyagipar, a fémipar, illetve a gépipar. Utóbbi a legjelentósebb, mivel a fel- dolgozóipari termelés közel felét adja. A gépiparon belül manapság az elektronikai gyártóipar és a jármúipar a legmeghatározóbb. Magyarország erőteljesen specializálódik a jármúipar irányába, ahol a bővítések messze felülmúlják a többi ágazatban tapasztaltakat (Bereczk, 2015). Viszont ez - mint a VW-botrány is ráirányította a figyelmet - jelentós kockázatot is jelent, mert az egy lábon állás nem ad kellő gazdasági biztonságot.

\section{A sikertényezők}

A sikertényezők olyan menedzsmentterületek vagy -eszközök, speciális megoldások, amelyekre különösen és folyamatosan figyelmet kell fordítani a siker jó esélyének biztosítása érdekében. Ezek a tényezők nagyban felelősek a célok sikeres megvalósításáért. Az empirikus kutatás során csak azok a múltban azonosított eszközök használhatók, amelyek egyértelmúen értelmezhetők és mérhetôk. Így a sikertényezők azonosítására törekvő kutatások eredményei alapján azonosított sikertényezók - amelyek pontos definícióját az azt azonosító kutatások adták - az 1. táblázatban láthatók.

\section{A kutatásban vizsgált sikertényezók}

\section{1. táblázat}

\begin{tabular}{|c|c|}
\hline Stratégiai sikertényezók & Strukturális sikertényezók \\
\hline $\begin{array}{l}\text { Finomhangolás } \\
\text { Időütemezés } \\
\text { Hosszú távú tervek } \\
\text { Megszabadulás a lassan } \\
\text { növekedő üzletektől } \\
\text { Terjeszkedés a kapcsolódó } \\
\text { üzletágak felé } \\
\text { Felelősségvállalás } \\
\text { Proaktivitás } \\
\text { Stratégia kommunikálása az } \\
\text { érintetteknek }\end{array}$ & $\begin{array}{l}\text { Egyszerú tagoltság } \\
\text { Szoros kapcsolat a vevővel } \\
\text { Számszerú mérési rendszer } \\
\text { Javaslatok kezelése, } \\
\text { ösztönzése } \\
\text { Döntéshozatal közel a } \\
\text { vevőhöz }\end{array}$ \\
\hline Kulturális sikertényezők & Vezetési sikertényezók \\
\hline $\begin{array}{l}\text { Elismerés } \\
\text { Csapatmunka } \\
\text { Menedzsment kinevelése } \\
\text { Értékrendszer } \\
\text { Alapérték kontra fejlődés } \\
\text { Univerzális munkaeró }\end{array}$ & $\begin{array}{l}\text { Szoros emberi kapcsolatok } \\
\text { Intuitivitás } \\
\text { Szúk felső vezetés } \\
\text { Tehetséggondozás } \\
\text { Döntések delegálása }\end{array}$ \\
\hline
\end{tabular}

Az első csoporthoz tartoznak a stratégiai sikertényezők, amelyek eszközök a jövőhöz, kihívásokhoz, környezethez való viszonyuláshoz.

Finomhangolás: a folyamatban lévő stratégia kismértékû megváltoztatása az új technológiák, társadalmi trendek, állami rendeletek, versenytársak új termékei hatására (Joyce et al., 2003). 
Idôiutemezés: időre vonatkozó teljesítménymutatók, áttekinthetô eljárások a váltásokra, illetve változási üteme meghatározható ritmust követ (Grove, 1997; Eisenhardt - Brown, 1998).

Hosszú távú tervek: a vállalat rendelkezik hosszú minimum 10 éves - idôtávra célokkal, és azok megvalósítása lépésről-lépésre kidolgozott (Collins - Porras, 2000).

Megszabadulás a lassan növekedö üzletektôl: a vállalat egészének növekedési ütemétől elmaradó üzletek, divíziók eladása vagy megszüntetése (Foster - Kaplan, 2001).

Terjeszkedés a kapcsolódó iületágak felé: egyedi képességek kiépítése a központi üzletágban, és azok kiaknázása. Erôteljes terjeszkedés a kapcsolódó iparágak felé (Zook - Allen, 2001).

Felelösségvállalás: szociális és környezeti szempontok beépítése saját akaratból, önkéntes alapon az üzleti múködésbe és az érintettekkel való kapcsolatokba (Porter - Kramer, 2007).

Proaktivitás: a vállalat jellemzően versenytársai előtt cselekszik, nem az eseményekre reagál, hanem megelőzi azokat (Collins - Porras, 2000).

Stratégia kommunikálása az érintetteknek: a stratégia egyértelmú, világos kommunikálása minden érintett részére (Joyce et al., 2003).

A második csoportot alkotják a strukturális sikertényezők, a szervezeti kialakítások a formális, informális információátadásokra, cselekvésekre.

Egyszerú tagoltság: egyszerú, lapos szervezeti felépítés. A végrehajtási szint közel van strukturálisan a felső vezetéshez (Joyce et al., 2003).

Szoros kapcsolat a vevóvel: törekvés tranzakcióknál mélyebb kapcsolatra a vevóvel. A belső rendszer olyan, miszerint a következő folyamat, az előző vevője. Mintha mindenki közvetlenül a végfelhasználóval lenne kapcsolatban (Peters - Waterman, 1982).

Számszerú mérési rendszer: számadatokkal dolgozó értékelési rendszer, melyet időszakonként felülvizsgálnak, módosítanak és az általa nyert adatokat elemzik (Spitzer, 2007).

Javaslatok kezelése, ösztönzése: szervezeti egység, megoldás, amellyel a munkatársak által benyújtott javító változtatások elbírálhatók és megvalósítók (Kotter - Heskett, 1992).

Döntéshozatal közel a vevóhöz: a lényeges döntések közel vannak vevőkhöz, illetve azokhoz, akik a vevőkkel közvetlenül kapcsolatban vannak (Joyce et al., 2003).

A kulturális sikertényezők (3. csoport), a sajátosságokból adódó megoldások, a közösség cselekedeteit, gondolatmódját befolyásoló tényezők.

Elismerés: teljesítmény tisztelete, elismerése és mások erre ösztönözése (Joyce et al., 2003).
Csapatmunka: egymás segítésén alapuló csapatmunka, összetartás. Az emberek szívesen járnak be dolgozni, mert egymást becsülik, tisztelik (Beer, 2009).

Menedzsment kinevelése: a vállalat a belső értékekre épít és maga alakítja, formálja vezetőit az alapvetó értékei, normái, ideológiái szerint (Collins - Porras, 2000).

Értékrendszer: a vállalat értékrendszerének tudatosítása a munkavállalókkal minden szinten megtörténik (Peters - Waterman, 1982).

Alapérték kontra fejlódés: a vállalat meg tudja tartani alapvető értékeit és céljait, miközben stratégiája és múködése alkalmazkodik a világ változásaihoz (Collins - Porras, 2000).

Univerzális munkaeró: a vállalat törekszik arra, hogy a munkavállalói több területen is bevethetôk legyenek (Dinya, 2008).

A 4. csoportot jelentô vezetési sikertényezők pedig arra vonatkoznak, hogy az irányításra jogosultak miként koordinálják, és késztetik a lehetô legjobbjukra a beosztottaikat.

Szoros emberi kapcsolatok: menedzsment napi kapcsolatban van az alsóbb szinteken dolgozó munkatársakkal, ami nemcsak hierarchikus, alá-fölérendelt viszony (Joyce et al., 2003).

Intuitivitás: a vezetés nemcsak szisztematikus módon, jól kialakult gyakorlat szerint történik, hanem intuitív módon, ösztönös megérzés szerint is (Dinya, 2008).

Szük felső vezetés: kis számú vezetőség, egyszerú felépítés (Peters - Waterman, 1982).

Tehetséggondozás: a felsố vezetés részt vesz a tehetségek kiválasztásában, képzésében (Joyce et al., 2003; Breene - Nunes, 2011).

Döntések delegálása: alkalmazottak bevonása a döntések előkészítésébe, meghozatalába, illetve a múködési mechanizmusok kialakításába (Dinya, 2008).

\section{A sikerkritériumok}

A sikerkritériumok azok a feltételek, amelyek értékelik a vállalatokat sikeresség szempontjából és általuk megállapítható a vállalatok sikeressége. Az egyes sikerkritériumok szerinti eredmények összetevői a sikeres vállalati múködésnek, így mint sikerkomponensek funkcionálnak. A siker kiemelkedő teljesítményt feltételez, ezért az azt leíró sikerkritériumok kialakításához a teljesítménymérés szolgált alapul, mivel a sikeresség vizsgálatához a vállalat teljesítményét minden érintett felé mérni kell. Ehhez pedig egy részletesebb, több szintủ rendszerre van szükség. Ilyen összetett mutatószámrendszer a teljesítményprizma, a Tableau de Board, Skandia Business Navigator, illetve a kiegyensúlyozott mutatószámrendszer, más néven balanced scorecard. A 
kutatásunk során a vizsgálathoz Robert S. Kaplan és David P. Norton (2002) által kidolgozott balanced scorecardot használtuk. Azért, mert ez a rendszer adja a legszilárdabb keretet, emellett minden érintett irányában megállapítható a vállalat teljesítménye és bővíthető. A szerzők alapvetően négy nézőpontot különböztetnek meg egy vállalat teljesítményének a méréséhez (Balaton et al., 2014), viszont felhívják a figyelmet arra, hogy ez függvénye a vizsgált szervezetnek. Annak, hogy milyen közegben múködik, milyen speciális céljai vannak (Kaplan - Norton, 2002). Jelenleg kiemelt szerepet kap a fenntarthatóság, ami ma már a stratégia kialakításánál elsődleges irányelv, és legalább annyira fontos, mint a korábban azonosított négy nézópont. Beépítését a balanced scorecard rendszerébe már többen próbálták. Megoldásként három lehetőség adódik (Zingales Hockerts, 2002):

- Szempontjainak integrálása a klasszikus négy nézőpontba: akkor érdemes használni, ha a fenntarthatóság tényezői a piaci mechanizmusok által hatnak.

- Új, ötödik nézópontként felvenni a rendszerbe a meglévő nézőpontok mellé: akkor érdemes használni, ha a fenntarthatóság stratégiai fontosságú, de hatását nem a piaci mechanizmusok által fejti ki, hanem „nem-piaci” tényezőként.

- Fenntarthatósági balanced scorecardok összeállítása: egy olyan új BSC-t kell kialakítani, ahol a fenntarthatóság minden további nézópontot maga alá rendel (Butler et al., 2011).

Ma már a fenntarthatóság legalább annyira fontos, mint a korábban azonosított négy nézőpont. Az első lehetőség - a beillesztés a hagyományos négy nézópontba - esetén a fenntarthatóság szempontja eltúnne, beolvadna, így az nem számítana kielégító megoldásnak. A szervezetek a fenntarthatósági szempontokat, mint „nem piaci” aspektusokat beépítik stratégiájuk kialakításánál a múködésbe (Butler et al., 2011). A piaci szempontok viszont eddig is, és ezután is kiemelten fontosak, ezért a harmadik lehetôség - a fenntarthatóságra koncentráló BSC-készítés - a piaci szempontokat könnyen elnyomhatja. Mindezek eredményeképpen a legjobb megoldás arra, hogy a vállalat minden nézópontját együttesen, egyenlően kezelje, a fenntarthatóság külön, ötödik nézópontként való kezelése. Ezáltal lehet beszélni egy olyan balanced scorecardról, ahol öt, egyenlő erô van kapcsolatban egymással és a vállalati céllal, misszióval.

Így ez az empirikus kutatás - az eddigi gyakorlattól eltéró módon - az elsők között elemzi úgy a vállalatok teljesítményét a balanced scorecard segítségével, hogy a fenntarthatósággal együtt már öt nézőpont szerint vizsgál. Ezáltal új, eddig nem azonosított összefüggések tárhatók fel.

A fenntarthatóság, mivel nem-piaci szempont a balanced scorecard logikai rendszerében alapvető helyre kerül, így - mint közvetett sikertényező - direkt és indirekt módon is hatással van a vállalat tanulási, fejlódési, múködési folyamatok, vevői és pénzügyi nézőpontjára (Figge et al., 2002; Zingales - Hockerts, 2002).

A fenntarthatóságra vonatkozó mutatószámok azonosításához a kutatás a GRI (Global Reporting Initiatives) útmutatóra támaszkodott, ami az ENSZ égisze alatt múködő holland székhelyú civil szervezet által összeállított, és jelenleg legelterjedtebb fenntarthatósági útmutató. Összefoglalja, és standardizálja, hogy milyen teljesítményadatokkal mérhetô fel egy szervezet fenntarthatósági múködése.

A fenntarthatósági nézőpont sikerének indikátorai

- a közhasznú céllal történt adományok, pénzbeli, természetbeni támogatások aránya a nettó árbevételhez viszonyítva,

- a kezdő diplomás bér, az átlagos bruttó diplomás kezdő fizetés a minimálbérhez viszonyítva,

- a vállalatra kiszabott környezetvédelmi- és jogszabályok be nem tartása miatti bírságok a nettó árbevételhez viszonyítva,

- a környezetvédelmi beruházásokra fordított öszszeg a teljes nettó árbevételhez viszonyítva,

- a vállalat által kibocsátott összes hulladék újrahasznosításának aránya,

\section{A siker indikátorai}

2. ábra 
- a vállalat által felhasznált összes energia hány százalékát adja megújuló (nap-, szél-, biomassza-, vízi- és geotermikus) energiaforrás,

- a női menedzsmenttagok száma a teljes menedzsment létszámhoz viszonyítva. (2. ábra)

\section{A kutatás alkalmazott módszertana}

A kutatás során használt kérdőív magyarázó változókra vonatkozó része a szakirodalmi kutatás által előre meghatározott négy csoportba sorolt - definíciói alapján meghatározott - sikertényezők használatának mértékére kérdez rá. A teljesítményadatok mérése esetében a kutatás az egyértelmú, számszerú adatokra fókuszált, amivel biztosítható a teljes objektivitás. A vizsgálatba bevont vállalatok egységeses kezelését, egymáshoz viszonyíthatóságát pedig arányszám-használattal érte el.

A gyakorlati elemzésnél a sikertényező csoportok vizsgálata faktorelemzéssel történt, maximum-like- hood eljárással, ami normál eloszlást feltételezve olyan becsléseket ad, amelyek a legnagyobb valószínúséggel létrehozzák a korrelációs mátrixot, és ezáltal a sikertényező faktorokat. A sikertényezők mint magyarázó változók és a főkomponens-elemzéssel megállapított sikert leíró sikerkomponensek közötti hatásvizsgálat eszköze az útelemzés volt, a balanced scorecard elemei között fennálló kapcsolatok miatt. A tényezők közötti korrelációk mutatják meg az összefüggéseket, amelyek segítségével felírhatók az útelemzéshez használt lineáris regressziós modellek. A modellek elemzése által pedig kirajzolódnak a belső hatások, utak.

\section{A kutatás folyamata}

Az adatgyújtés kérdőíves lekérdezéssel történt 2014. augusztustól novemberig. A kérdéseket 4411 vállalatvezetó kapta meg, 464-en válaszoltak, és ebből 230 darab - a teljes kiküldés 5,21\%-a - volt használható, ami bőven meghaladja az elemzéseknél használt sta-

\section{A sikertényezôk rotált faktormátrixa}

\begin{tabular}{|l|c|c|c|c|c|}
\hline & \multicolumn{4}{|c|}{ Faktor } \\
\cline { 2 - 6 } & $\begin{array}{c}\text { Kifelé } \\
\text { irányuló } \\
\text { stratégiai } \\
\text { sikertényezók }\end{array}$ & $\begin{array}{c}\text { Befelé } \\
\text { irányuló } \\
\text { stratégiai } \\
\text { sikertényezók }\end{array}$ & $\begin{array}{c}\text { Strukturális } \\
\text { sikertényezők }\end{array}$ & $\begin{array}{c}\text { Kulturális } \\
\text { siker- } \\
\text { tényezók }\end{array}$ & $\begin{array}{c}\text { Vezetési } \\
\text { siker- } \\
\text { tényezók }\end{array}$ \\
\hline $\begin{array}{l}\text { Stratégia módosítása új társadalmi } \\
\text { trendek esetén }\end{array}$ & 0.737 & 0,044 & 0,086 & $-0,070$ & 0,091 \\
\hline Előre megalkotott eljárások az átmenetekre & 0.543 & 0,124 & 0.254 & $-0,029$ & 0,216 \\
\hline Összhang a piac változási ritmusával & 0.841 & 0,038 & 0,123 & 0,014 & 0,182 \\
\hline Törekvés üzletág ütemének meghatározása & 0.545 & 0,118 & 0,136 & $-0,045$ & 0,133 \\
\hline Stratégia kidolgozása hosszú távra & $-0,003$ & 0.529 & 0,030 & 0,001 & $-0,057$ \\
\hline Stratégiát minden munkatárs ismeri. & 0,172 & 0.833 & 0,119 & $-0,060$ & 0,189 \\
\hline $\begin{array}{l}\text { Stratégia kommunikálása minden } \\
\text { érintett részére }\end{array}$ & 0,164 & 0.768 & 0,158 & $-0,109$ & 0.276 \\
\hline $\begin{array}{l}\text { Szolgáltató-vevó hozzáállású szervezet } \\
\text { kialakítás }\end{array}$ & 0,248 & 0,128 & 0.631 & $-0,217$ & 0,233 \\
\hline Szervezeti megoldás a javaslatok elbírálására & 0,178 & 0,093 & 0.912 & $-0,088$ & 0,127 \\
\hline $\begin{array}{l}\text { Szervezeti egység a javaslatok } \\
\text { megvalósítására }\end{array}$ & 0,168 & 0,113 & 0.790 & $-0,016$ & 0,155 \\
\hline Csapatmunka & $-0,031$ & 0,011 & $-0,061$ & 0.802 & 0,019 \\
\hline Munkatársak több munkakört képesek ellátni & 0,027 & 0,015 & $-0,006$ & 0.704 & 0,017 \\
\hline Intuitív módon is történó munkaszervezés & $-0,138$ & $-0,211$ & $-0,179$ & 0.526 & $-0,087$ \\
\hline Vezetés részt vesz a tehetségek képzésében. & 0,187 & 0,206 & 0,136 & $-0,060$ & 0.646 \\
\hline $\begin{array}{l}\text { Beosztottak bevonása a döntések } \\
\text { elő́készítésébe }\end{array}$ & 0,196 & 0,034 & 0,191 & $-0,106$ & 0.760 \\
\hline $\begin{array}{l}\text { Beosztottak bevonása a döntések } \\
\text { meghozatalába }\end{array}$ & 0,120 & $-0,008$ & 0,085 & 0,054 & 0.673 \\
\hline $\begin{array}{l}\text { Beosztottak bevonása a folyamatok } \\
\text { kialakításába }\end{array}$ & 0,110 & 0,120 & 0,080 & 0,036 & 0.395 \\
\hline
\end{tabular}


tisztikai módszerekhez minimálisan előírt 200 darabos mintaelemszámot. Az átlagosnál alacsonyabb felhasználhatósági arány oka, hogy a teljesítményadatok begyújtésénél meghatározó szerepet töltött be az objektivitás. A pontos adatok megadása hosszabb utánajárást kívánt meg a kitöltő́ktől, ami miatt sok esetben a teljesítményadatokat nagyon hiányosan töltötték ki, vagy teljesen üresen hagyták. Több megkeresett vállalat is jelezte, hogy azért nem küldte vissza kitöltve kérdőívet, mert azt a vállalati titoktartási eloórások miatt nem teheti meg.

\section{A kutatás eredményei}

A faktoranalízis eredményei megmutatják, hogy a feltételezett változók, és azok feltételezett csoportjai miként jelennek meg. Az elemzés során a Khí-négyzet modell szignifikanciaértéke 0,106 , ami meghaladja a határt jelentő 0,05-ös szintet, így a mért és látens struktúra illeszkedik. Ez azt is jelenti, a kapott faktorok kellóképpen leírják a változókat.

A sikertényező-elemekre vonatkoztatott Kaiser-Meyer-Olkin mutató értéke 0,792, amely alátámasztja, hogy a változók alkalmasak faktorelemzésre, mivel a KMO mutató meghaladja az elfogadhatósági határt jelentő 0,5-ös értéket. A Bartlett-teszt 0,000 szinten szignifikáns értéke pedig ezt megerôsíti. Ez azt jelenti, hogy a változók közötti parciális korrelációk megfelelően alacsonyak, így nemcsak változópárok erós kapcsolata tapasztalható.

A 0,25-ös minimum szintet el nem éró kommunalitással rendelkező tényező́k kizárása után, a végleges faktorstruktúrát öt faktor alkotja. Az így megórzött információmennyiség 55,42\%. A kapott rotált faktorsúly-mátrix mutatja, hogy a faktorokat milyen elemek, milyen súllyal építik fel (2. táblázat).

Az elemzés során kiesett tényezők külön vizsgálatánál az állapítható meg, hogy a gyenge kapcsolódások miatt a változókra a faktorok alkotásánál gyenge kommunalitás jellemző. Függetlenek, ezért nem rendeződnek a sikertényező-rendszerbe.

Az elemzésben maradt változók alapján a sikeres vállalati múködést elősegítő öt faktor:

- „kifelé irányuló stratégiai sikertényezők” (KISSF) faktor a változásokat helyezi a középpontba,

- „,befelé irányuló stratégiai sikertényezők” (BISSF) faktor a hosszú távú terveket, és azok belső tudatosítását foglalja magában,

- „strukturális sikertényezők” (SSF) faktor a kiszolgálás és folyamatos javítás elősegítésének szervezeti megoldásainak az összessége,

- „kulturális sikertényezők” (KSF) faktor, a szervezeti normák és értékek, amelyek alapját adják a munkaszervezésnek,
- „Vezetési sikertényezők” (VSF) faktor pedig azt tartalmazza, hogy a vezetők milyen módon fejlesztik beosztottaikat és osztják le a feladatokat.

Öt csoport jött létre, ami alátámasztotta a feltételezett négy tényezőcsoportot úgy, hogy a stratégiai sikertényező́k két részre különülttek el, a kifelé- és a befelé irányuló sikertényezőkre.

Egyedül az intuitivitás az a tényező, amely nem az elózetesen besoroltak szerint helyezkedett el. A tényező besorolása már az elméleti azonosításnál kérdésesnek bizonyult, mivel erôsen kultúrafüggő́. Végül a gyakorlati vizsgálat egyértelmúvé tette, hogy nem a vezetésnél, hanem a kultúránál kell figyelembe venni, mint a kultúra által befolyásolt sikertényezőt.

A változók közötti hatások vizsgálatához használt útmodell létrehozásának alapját a változók közötti öszszefüggéseket mutató Pearson-féle korrelációk adták. Csak ott léphet fel hatás, azok a változók köthetóek öszsze, ahol szignifikáns összefüggés mutatkozik. Az utak kialakításához viszont egyértelmú logikával irányt kellett adni. Ez a kutatási modell és a szakirodalmi kutatás alapján történt meg, két egyértelmú szabály szerint. Az elsố a magyarázó és magyarázott változók elrendezése. Csakúgy, mint a regressziónál, az egymástól független magyarázó változók irányából mutat a hatás a magyarázott változók felé. A másik szabályt a szakirodalmi kutatás adta, és a magyarázott oldalra vonatkozik. Sikert leíró komponensek alapja a teljesítménymérés, amelynek eszköze a balanced scorecard. A balanced scorecard nézópontjai közötti kapcsolatirányokat Norton és Kaplan tisztán leírja, a bevont fenntarthatósági nézópont pedig, mivel nem piaci szempont, mindegyik tényezőre kihat (Kaplan - Norton, 2002; Zingales Hockerts, 2002). A két szabály által meghatározott logikát követve a szignifikáns korrelációkból kiindulva a 3. ábra által látható hatásirányok állapíthatóak meg.

\section{Az elemzés által kialakult útmodell}

3. ábra

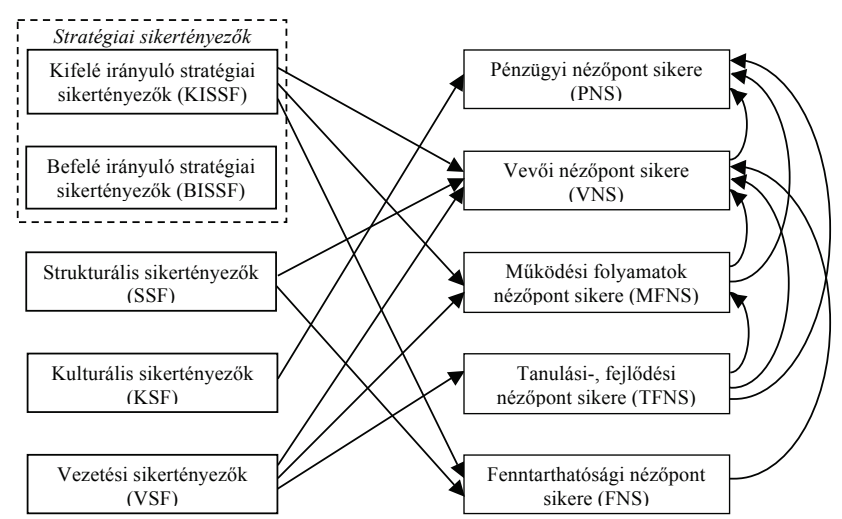


A hatásirányok alapján öt lineáris regressziós modellt lehet azonosítani.

1. PNS $=\alpha_{1} * \mathrm{KSF}+\alpha_{2} * \mathrm{VNS}+\alpha_{3} * \mathrm{MNS}+\alpha_{4} * \mathrm{TFNS}+\mathrm{R}$

2. $\mathrm{VNS}=\beta_{1} * \mathrm{KISSF}+\beta_{2} * \mathrm{SSF}+\beta_{3} * \mathrm{VSF}+\beta_{4} * \mathrm{MNS}+\beta_{5} *$

$\mathrm{TFNS}+\beta_{6} * \mathrm{FNS}+\mathrm{R}_{2}$

3. $\mathrm{MNS}=\gamma_{1} * \mathrm{KISSF}+\gamma_{2} * \mathrm{VSF}+\gamma_{3} * \mathrm{TFNS}+\mathrm{R}_{3}$

4. $\mathrm{TFNS}=\delta_{1} * \mathrm{VSF}+\mathrm{R}_{4}$

5. $\mathrm{FNS}=\varepsilon_{1} * \mathrm{KISSF}+\varepsilon_{2} * \mathrm{BISSF}+\varepsilon_{3} * \mathrm{SSF}+\mathrm{R}_{5}$

ahol:

$P N S$ a pénzügyi nézópont sikere,

$V N S$ a vevői nézőpont sikere,

MFNS a múködési folyamatok nézőpont sikere,

TFNS a tanulási-, és fejlődési nézőpont sikere,

FNS a fenntarthatósági nézőpont sikere,

KISSF a kifelé irányuló stratégiai sikertényező faktor,

$B I S S F$ a befelé irányuló stratégiai sikertényező faktor,

SSF a strukturális sikertényező faktor,

$K S F$ a kulturális sikertényező faktor,

$V S F$ a vezetési sikertényező faktor,

$\alpha_{1}, \alpha_{2}, \alpha_{3}, \alpha_{4}, \beta_{1}, \beta_{2}, \beta_{3}, \beta_{4}, \beta_{5}, \beta_{6}, \gamma_{1}, \gamma_{2}, \gamma_{3}, \delta_{1}, \varepsilon_{1}, \varepsilon_{2}$ a parciális regressziós együtthatók,

$R_{E S I D}, R E S I D_{2}, R E S I D_{3}, R E S I D_{4}, R E S I D_{5}$ a regressziós egyenletek hibatagjai.

A regressziós modellek érvényességére vonatkozó szignifikanciavizsgálat szerint mindegyik modell szignifikáns. A változókra, és a hibatagokra előírt feltételek ellenőrzése megtörtént, és minden esetben megfelelóséget mutatott. A modellek a negyedik kivételével, 10 és 20 százalék között magyarázzák a valóságot. A negyedik modellnél a magyarázott hányad 3,6\%, ami nagyon alacsony, ezért a szerepeltetése az útmodellben nem indokolt. A többi négy modell esetén, az első 13,1, a második 17,6, a harmadik 11,4 , a negyedik 11,0 százalékban magyarázza a valóságot. A $20 \%$ alatti értékek nem túl magasak, de figyelemre méltóak, mivel a teljes objektív élethelyzet összetett, és az arra vonatkoztatott modell annak csak egy kisebb részét tudja lefedni (Székelyi - Barna, 2005). Emellett a sikert befolyásoló háttértényezők száma és kombinációja igen nagyszámú, és a vállalatokra jellemző egyéni jellemvonások, kompetenciák, motivációk nem szerepelnek a modellben (Veroszta, 2010). Jelen kutatás útelemzésénél elfogadott négy modell esetén a determinisztikus együttható $\left(\mathrm{R}^{2}\right)$, meghaladja a kritikusnak tartott 0,1 értéket (Moksony, 1998; Hunyadi, 2000), így az általuk azonosított hatásokat elfogadhatónak tekintettük. Mindemellett természetesen a korrigált $\mathrm{R}$ négyzetekből látszik, hogy Magyarországon a feldolgozóiparban a nemzetközi kutatások által azonosított tényezők csak kisebb mértékben határozzák meg a sikert. Azt a hányadot, amely jóval nagyobb, és nem sikerült megmagyarázni, más tényezők adják.

\section{Az elemzés által kialakult útmodell}

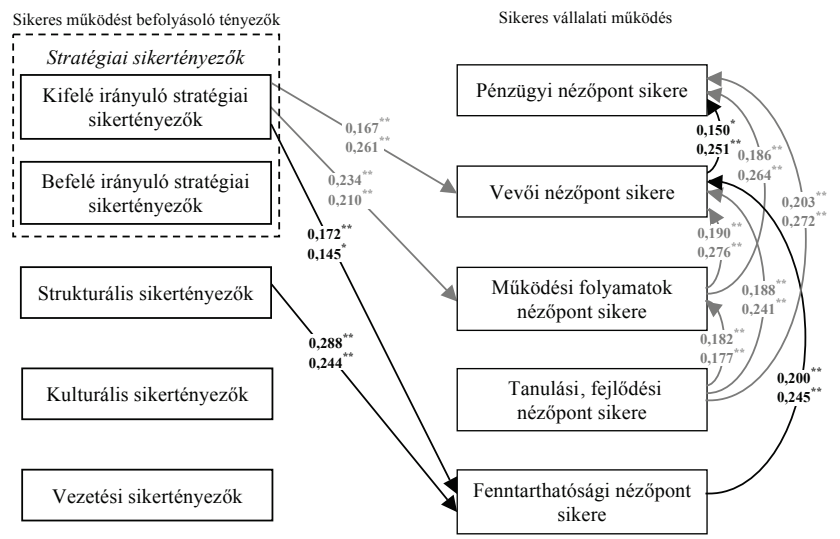

Az útmodellt mutató 4. ábrán a nyilakon a felső szám a regressziós egyenes meredekségét jelző $\beta$ értéket mutatja, az alsó szám pedig a korreláció erōsségére vonatkozó Pearson-féle korrelációs együttható értéke. A számok mellett található kettős csillag az 1 százalékos, az egy csillag pedig az 5 százalékos szignifikancia szintet jelzi.

A hatásokat összefoglaló 3. táblázat szemlélteti, hogy milyen módon törekednek a vizsgálatba bevont vállalatok a fenntarthatósági nézôpont esetén a sikerre, a minél jobb eredményre.

\section{A sikertényező-faktorok kimutatott hatásai a fenntarthatósági nézópontra}

\begin{tabular}{|l|c|c|c|}
\hline \multirow{2}{*}{ Magyarázó változók } & \multicolumn{3}{|c|}{$\begin{array}{c}|c| \\
\text { senntorés }\end{array}$} \\
\cline { 2 - 4 } & Direkt & Indirekt & Teljes \\
\hline $\begin{array}{l}\text { Kifelé irányuló stratégiai } \\
\text { sikertényezők }\end{array}$ & 0,172 & & 0,172 \\
\hline $\begin{array}{l}\text { Befelé irányuló stratégiai } \\
\text { sikertényezők }\end{array}$ & & & \\
\hline \begin{tabular}{l} 
Strukturális sikertényezők \\
\hdashline Kulturális sikertényezők
\end{tabular} & 0,288 & & 0,288 \\
\hline Vezetési sikertényezók & & & \\
\hline
\end{tabular}

$\mathrm{Az}$ útelemzés eredményei szerint a fenntarthatósági nézőpont sikerére a kifelé irányuló stratégiai$(\beta=0,172$, szig. $=0,007)$, illetve a strukturális $(\beta=0,288$, szig. $=0,000)$ sikertényező faktorok hatnak (3. táblázat). 
Eszerint a környezeti és társadalmi teljesítmény fokozható, ha a vállalat előre feltérképezi az eshetóségeket, és felkészül a változásokra. Meghatározók emellett a strukturális sikereszközök, a vevőorientált szempontok szerinti, és a fejlesztéseket tisztán ösztönző belső rendszer kialakítása. Ez is mutatja, hogy az alkalmazottak a fejlesztéseknél, jobbító javaslatoknál kiemelten fontos- li elégedettségüket, elismerésüket, ami által nagyobb mértékben választják a vállalat szolgáltatásait, termékeit, ami pénzügyi oldalon is pozitív hatással van.

A strukturális sikertényezők esetén a vevői nézőponttal kimutatott közvetett kapcsolatot alátámasztva a vevőorientált szervezeti felépítés a vevői elvárások miatt összpontosít a fenntarthatóságra. Továbbá az

A fenntarthatósági nézópont sikerének hatásai a további nézőpontok sikerére

4. táblázat

\begin{tabular}{|c|l|c|c|c|}
\hline \multirow{2}{*}{ Magyarázó változó } & \multicolumn{1}{|c|}{ Magyarázott változók } & \multicolumn{2}{c|}{ Hatás } \\
\cline { 3 - 5 } & & Direkt & Indirekt & Teljes \\
\hline \multirow{4}{*}{ Fenntarthatósági nézőpont sikere } & Pénzügyi nézópont sikere & & 0,030 & 0,030 \\
\cline { 2 - 5 } & Vevő́i nézőpont sikere & 0,200 & & 0,200 \\
\cline { 2 - 5 } & Múködési folyamtok nézópont sikere & & & \\
\cline { 2 - 5 } & Tanulási és fejlódési nézőpont sikere & & \\
\hline
\end{tabular}

nak tartják a környezeti, társadalmi kérdéseket. Ez pedig indirekt módon a vevői nézőpontra is hatással van, ami azt mutatja, hogy az így kialakított rendszer által a vevők elégedettebbek, és az ügyfélszám nő.

A 4. táblázat azt mutatja be, hogy a fenntarthatósági eredmények hogyan hatnak a vállalatok további szempontjai esetén a sikerre. Ezzel pedig hogyan közvetítik a sikert elősegítő eszközök hatásait a piaci szempontok irányában.

Megállapítható, hogy a fenntarthatóság, bevont szempont egyedül a vevói nézópontra hat direkt módon $(\beta=0,200$, szig. $=0,001)$, és ezáltal közvetett módon befolyásolja a pénzügyi eredményeket (4. táblázat). Továbbá hidat képez a kifelé irányuló stratégiai és a strukturális sikertényező faktorok irányából érkező hatások számára is.

Az eredmények azt mutatják, hogy a kulturális sikertényezők, mint az egymás segítésén alapuló csapatmunka, a több területen is bevethető alkalmazottak, illetve az intuitív munkaszervezés a kutatás során nem mutattak ki hatást a fenntarthatóságra, illetve a többi nézôpontra sem, Ez elmondható a vezetési sikertényezôkkrôl is. Így a vezetôk részvétele a tehetségek képzésében, és az alkalmazottak bevonása a vizsgált vállalatok esetén szintén nem eredményezett szignifikáns módon jobb fenntarthatósági eredményt.

\section{Következtetések}

Az eredmények azt mutatják, hogy Magyarországon a fenntarthatóság egyelőre még erósen marketingszempont. Hatását nem belsőleg, hanem az ügyfél irányában fejti ki. A vevők számára értékgeneráló hatású, növe- mutatja, hogy a kiemelt környezettudatos gondolkodás alapvetố a jelenlegi 30 év alatti generáció esetén (Braun, 2013). A fiatalabb munkatársak aktivitása jelentős a jobbító javaslatok tételénél és megvalósításánál. Az erre vonatkozó strukturált rendszerek és egységek ezt a tevékenységet katalizálják, ami elósegíti a fenntarthatósági sikert.

A kifelé irányuló stratégiai sikertényezők fenntarthatóságra gyakorolt hatásaiból az állapítható meg, hogy a társadalmi trendek és a piaci ritmus követése számottevő környezetre és társadalomra vonatkozó tevékenységet feltételez, ami javítja közvetlen módon az ügyfelek elégedettségét, és pénzügyi felhajtóerővel jár.

\section{Összevetés a korábbi kutatási eredményekkel}

A kutatásunk eredményei közül a kifelé irányuló stratégiai sikertényezők hatásai alátámasztják Andrew Grove-nak, az Intel korábbi elnökének véleményét, miszerint elsődlegesen a változásokra kell összpontosítani. Véleménye szerint az inflexiós pontok a meghatározóak, mivel ettól függ, hogy a vállalat mennyire tudja menedzselni a változásokat. Grove meggyőződése (1997), hogy ezeknek a pontoknak, átmeneteknek az ütemezése a vállalat jövójének, fenntarthatóságának a kulcsa. Ezt támasztja alá Eisenhardt és Brown (1998) is, akik arra jutottak, hogy azok a szervezetek lesznek sikeresek, amelyek a váltásról egyszerú, áttekinthetô, megkoreografált eljárással rendelkeznek, és saját ütemüket a piac ütemével összhangba hozzák. A XXI. században pedig ennek az ütemnek az egyik mozgatója a fenntarthatóság. A finomhangolás fontosságát mutató összefüggések egyeznek Joyce és munkatársai (2003) azon megál- 
lapításával, miszerint elengedhetetlen a piac folyamatos figyelése, változások esetén a stratégia finomhangolása. Az eredmények nem osztják Kotter és Heskett (1992) korábbi közös munkájának vélekedését, miszerint a kulturális eszközök hatása jelentős. Magyarországon tehát a kulturális alapokon nyugvó megoldásokat kevésbé használják a vállalatok, mint a stratégiai és strukturális eszközöket. Fontos megemlíteni a strukturális eszközök hatását. A jobbító javaslatokat elősegítő szervezeti struktúra eróteljes sikergeneráló hatása azt mutatja, hogy jelenleg a fejlesztéseknél a fenntarthatósági szempontok is megjelennek. Ez magyarázható akár az új generációk munkaerópiacra lépésével is. Ahogy Braun (2013) következtet, az Y után egy következő generáció jön, amelynél központi tényezó a fenntarthatóság. Minden cselekedetüket áthatja ez a gondolkodásmód, így amennyiben a vállalatok az ilyen irányú törekvéseket támogatják, az alkalmazottak ötleteivel a fenntarthatósági teljesítmény javulni fog.

\section{Összefoglalás}

A kutatás elemezte a korábbi évtizedekben azonosított sikertényezőket, és vizsgálta azok hatását a Magyarországon múködő 50 fónél nagyobb létszámú, feldolgozóiparban tevékenykedő vállalatok kiemelkedő, sikeres múködésre, összpontosítva fenntarthatóságra. Az elemzési módszerek kiválasztásánál kiemelten szempont volt az objektivitás, és az egyértelmú eredménykezelés.

A tanulmány elhelyezte a sikertényezóket a stratégiai menedzsment rendszerében. Öt sikertényező faktort azonosított, amelyek négy területet ölelnek fel: a stratégiai, amely tovább bontható a kifelé- és befelé irányuló tényezőkre, illetve a strukturális, kulturális és vezetési sikertényezőket. A központi változó a fenntarthatósági siker volt. A siker leírásához a balanced scorecard képezte az alapot, amelyet a fenntarthatósági nézóponttal kiegészítve felállítottuk az öt sikerkomponenst. A hatások feltárása után pedig láthatóvá vált, hogy mely eszközök hatnak a fenntarthatóságra, és ezek a hatások hogyan jutnak el a nem piaci szempontokhoz.

A sikertényező-faktorok és a sikerkritériumok csoportjai között feltárt összefüggések azt mutatják, hogy a stratégiai sikertényező́k esetén a kifelé irányuló eszközök és a strukturális sikertényezók mutatnak pozitív befolyást a fenntarthatóság irányában. A vezetói és kulturális eszközök pedig nem. A fenntarthatóság pedig közvetlenül hat a vevőii, és ezáltal közvetetten a pénzügyi nézőpont sikerére.

Az eredmények ismeretében további lehetséges kutatási irány lehet a vizsgálat megismétlése szabályos időközönként. Így láthatóvá válhat, mi változott, mely sikertényezők használatának mértéke, befolyása módosult. A vizsgálat kiterjeszthető más országokra, vagy más iparágakra, amivel feltárható, hogy máshol felfedezhető-e eltérô eszközhasználat. További lehetôség a kutatás elvégzése strukturális egyenletek modellezésével (SEM), amellyel a sikert generáló mechanizmusok más vetületben is megismerhetők.

A feltárt összefüggések megmutatják, hogy a vállalatok fenntarthatósági sikerének esélye, teljesítménye, milyen tevékenységekkel javítható. Az aktuális pozíció azonosítása után a vezetô láthatja, milyen konkrét sikertényező használat ajánlott a fenntarthatóság fejlesztésére, és ezáltal a további szempontok eredményeinek fokozására.

\section{Felhasznált irodalom}

Angyal, Á. (2005): Vállalati felelősség, mint érték. Vezetéstudomány, 36(1), 2-12. o.

Balaton, K. - Hortoványi, L. - Incze, E. - Laczkó, M. - Szabó, Zs. R. - Tari, E. (2014): Stratégiai menedzsment. Budapest: Akadémiai Kiadó

Bárth-Fehér, Sz. (2012): Fenntarthatóság a hazai vállalati gyakorlatban - A ,Versenyben a világgal” kutatási program 2009. évi kérdốves felmérés eredményeinek vizsgálata. Vezetéstudomány, 43(10), 44-55. o.

Beer, M. (2009): High Commitment, High Performance: How to Build a Resilient Organization for Sustained Advantage. San Francisco: John Wiley \& Sons

Bereczk, Á. (2015): A beruházások eloszlásának lehetséges okai Magyarországon. in: Csiszárik-Kocsir, Á. (szerk.) (2015): Vállalkozásfejlesztés a XXI. században V.: tanulmánykötet. Budapest: Óbudai Egyetem Keleti Károly Gazdasági Kar, 8-18. o.

Braun, R. (2013): A vállalatok politikája: Vállalati, társadalmi felelősségvállalás, vállalati közösségek és a vállalati stratégia jövője. Vezetéstudomány, 44(1), 18-28. o.

Brebán, Zs. (2009): Alternatív globalizációs kultúra. Valóság, 52(4), 8-17. o.

Breene, R. T. S. - Nunes, P. F. (2011): Reinvent Your Business Before It's Too Late. Harvard Business Review, 89(1-2), 80-87. o.

Butler, P. B. - Larsen-Hallock, L. - Lewis, R. - Glenn, C. - Armstead, R. (2011): Metrics for Integrating Sustainability Evaluations Into Remediation Projects. Remediation, 21(3), 81-87. o.

Collins, C. C. - Porras, J. I. (2000): Built To Last: Successful Habits of Visionary Companies. (3rd ed.); London: Random House Business Books

Csath, M. (2008): Interkulturális menedzsment. Budapest: Nemzeti Tankönyvkiadó

Dinya, L. (2008): Szervezetek sikere és válsága. Budapest: Akadémiai Kiadó

Eisenhardt, K. M. - Brown, S. L. (1998): Time Pacing: 
Competing in Markets that Won't Stand Still. Harvard Business Review, 76(2), 59-69. o.

Figge, F. - Hahn, T. - Schaltegger, S. - Wagner, M. (2002): The Sustainability Balanced Scorecard Linking Sustainability Management to Business Strategy. Business Strategy and the Environment, 11(5), 269-284. o.

Foster, R. - Kaplan, S. (2001): Creative Destruction: Why Companies That Are Built to Last Underperform the Market - and How to Successfully Transform Them. New York: Currency Doubleday

Fülöp, Gy. (2013): Vállalati fenntarthatósági stratégiák és vezetôi képességek. in: Karlovitz, J. T. (szerk.) (2013): Ekonomické štúdie - teória a prax: Gazdasági tanulmányok - elmélet és gyakorlat. Komárno: International Research Institute, 395-403. o.

Fülöp, Gy. - Hódi Hernádi, B. (2014): A vállalati fenntarthatósági stratégia sikertényezője a fenntarthatósági számvitel. Vezetéstudomány, 45(4), 2-17. o.

Grove, A. (1997): Only the Paranoid Survive. New York: Harper Collins Publishers

Hunyadi, L. (2000): A determinációs együtthatóról. Statisztikai Szemle. 78(9), 753-765. o.

Joyce, W. - Nohria, N. - Robertson, B. (2003): What Really Works: The 4+2 Formula for Sustained Business Success. New York: HarperBusiness

Kaplan, R. S. - Norton, D. P. (2002): A Stratégiaközpontú szervezet: Hogyan lesznek sikeresek a Balanced Scorecard vállalatok az új üzleti környezetben? Budapest: Panem Kiadó

Kotter, J. P. - Heskett, J. L. (1992): Corporate Culture and Performance. New York: Free Press

Kukely, Gy. (2008): A külföldi múködőtőke beruházások hatása az ipar területi folyamataira Magyarországon, különös tekintettel a delokalizációra. PhD értekezés. Budapest: ELTE

Moksony, F. (1998): A kicsi szép. A determinációs együttható értelmezése és használata a szociológiai kutatásokban. Szociológiai Szemle, 77(4), 3-17. o.
Németh, P. (2013): A kereskedelmi láncok CSR-tevékenysége - a versenyképességük fokozása. Vezetéstudomány, 44(3), 61-71. o.

Peters, T. J. - Waterman, R. H. (1982): In search of excellence: Lessons from America's best-run companies. New York: Harper \& Row

Porter, M. E. - Kramer, M.R. (2007): Stratégia és társadalom, a versenyelőny és a vállalatok társadalmi felelőssége. Harvard Business Manager, 9(2), 6-20. o.

Spitzer, D. R. (2007): Transforming Performance Measurement: Rethinking the Way We Measure and Drive Organizational Success. New York: AMACOM

Székelyi, M. - Barna, I. (2005): Túlélőkészlet SPSShez. Budapest: Typotex Kiadó

Vas, Zs. - Legyel, I. - Szakálné Kanó, I. (2015): Regionális klaszterek és agglomerációs előnyök: feldolgozóipar a magyar városrégiókban. Tér és Társadalom, 29(3), 49-72. o.

Vápár, J. (2013): A német múködőtőke-befektetések Magyarországon. Tér és Társadalom, 27(1), 129-144. o.

Veroszta, Zs. (2010): A munkaerő-piaci sikeresség dimenziói frissdiplomások körében. in: Garai, O. - Horváth, T. - Kiss, L. - Szép, L. - Veroszta, Zs. (szerk.) (2010): Frissdiplomások 2010. Budapest: Educatio, 11-36. o. (Diplomás pályakövetés).

Zingales, F. G. G. - Hockerts, K. (2002): Nachaltige Balanced Scorecard. Beispiele aus Literatur und Praxis. in: Schaltegger, S. - Dyllick, T. (eds.) (2002): Nachhaltig managen mit der Balanced Scorecard. Konzept und Fallstudien. Wiesbaden: Gabler, 151166. o.

Zook, C. - Allen, J. (2001): Profit From the Core: Growth Strategy in an Era of Turbulance, Boston: Harvard Business School Press

A cikk beérkezett: 2016. április Lektorálás után elfogadva: 2016. december

\section{E SZÁMUNK SZERZŐI}

Pandurics Anett, közgazdász, PhD-jelölt, a Budapesti Corvinus Egyetem; Dr. Ujhelyi Mária, egyetemi docens, Debreceni Egyetem; Dr. Kun András István, egyetemi docens, Debreceni Egyetem; Apáthy M. Sándor, PhD-hallgató, Budapesti Corvinus Egyetem; Dr. Vörösmarty Gyöngyi, egyetemi docens,Budapesti Corvinus Egyetem; Dr. habil. Berényi László, PhD. egyetemi docens, Miskolci Egyetem; Dr. Simay Attila, PhD, egyetemi adjunktus, Károli Gáspár Református Egyetem; Gáti Mirkó, egyetemi tanársegéd, Budapesti Corvinus Egyetem; Dr. Prónay Szabolcs, egyetemi adjunktus, Szegedi Tudományegyetem; Dr. Keszey Tamara, egyetemi docens, Budapesti Corvinus Egyetem; Dr. Buzás Norbert, egyetemi docens, Szegedi Tudományegyetem; Bóna Péter, folyamatfejlesztő, Ph.D. hallgató, Denso Gyártó Magyarország Kft.; Dr. habil. Horváth Csaba, egyetemi docens, intézetigazgató, Óbudai Egyetem 